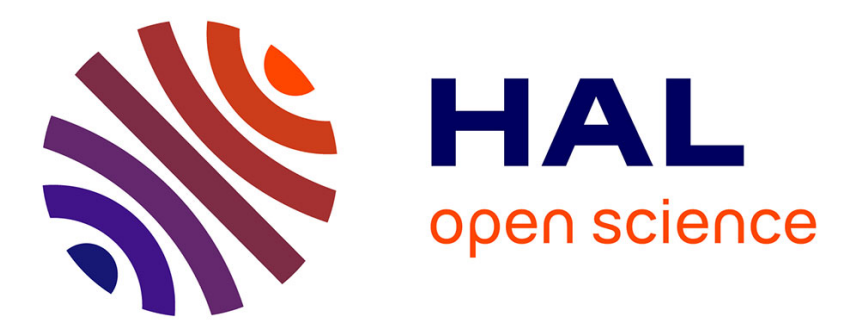

\title{
New characteristics of the male reproductive system in the Meliponini bee, Friesella schrottkyi (Hymenoptera: Apidae): histological and physiological development during sexual maturation
}

Pedro Brito, Uyrá Zama, Heidi Dolder, José Lino-Neto

\section{To cite this version:}

Pedro Brito, Uyrá Zama, Heidi Dolder, José Lino-Neto. New characteristics of the male reproductive system in the Meliponini bee, Friesella schrottkyi (Hymenoptera: Apidae): histological and physiological development during sexual maturation. Apidologie, 2010, 41 (2), 10.1051/apido/2009071. hal-00892067

\section{HAL Id: hal-00892067 https://hal.science/hal-00892067}

Submitted on 1 Jan 2010

HAL is a multi-disciplinary open access archive for the deposit and dissemination of scientific research documents, whether they are published or not. The documents may come from teaching and research institutions in France or abroad, or from public or private research centers.
L'archive ouverte pluridisciplinaire HAL, est destinée au dépôt et à la diffusion de documents scientifiques de niveau recherche, publiés ou non, émanant des établissements d'enseignement et de recherche français ou étrangers, des laboratoires publics ou privés. 


\title{
New characteristics of the male reproductive system in the Meliponini bee, Friesella schrottkyi (Hymenoptera: Apidae): histological and physiological development during sexual maturation*
}

\author{
Pedro BRITo ${ }^{1}$, Uyrá ZAMA ${ }^{2}$, Heidi DoldeR ${ }^{1}$, José LINO-NETO ${ }^{3}$ \\ ${ }^{1}$ Departamento de Anatomia, Biologia Celular e Fisiologia, Instituto de Biologia, UNICAMP, PO Box 6109, \\ Campinas, São Paulo, CEP 13083-863, Brazil \\ ${ }^{2}$ Departamento de Ciências Biológicas, UFOP, Ouro Preto, Minas Gerais, CEP 35400-000, Brazil \\ ${ }^{3}$ Departamento de Biologia Geral, UFV, Viçosa, Minas Gerais, CEP 36570-000, Brazil
}

Received 24 April 2009 - Revised 28 August 2009 - Accepted 5 September 2009

\begin{abstract}
Despite the biological importance of Meliponini bees, there are still many doubts about their reproductive physiology and phylogeny. When compared with other bee species studied up to now, the reproductive system of Friesella schrottkyi (Friese) has very different characteristics during sexual maturation, which includes: (1) the release of individualized testicular spermatozoa, rather than spermatozoa in bundles, (2) spermatozoa reaching the seminal vesicles only nine days after emersion of the adult bees, (3) holocrine secretion carried out by the seminal vesicle epithelium, (4) big lipid droplets abundant in the seminal vesicle epithelium and (5) membranous inclusions found in the seminal vesicle epithelium during the period of sexual maturation. These characteristics may represent important physiological characteristics as well as evolutionary differences in relation to other Meliponini studied and may be useful in studies of this bee group, as soon as similar descriptions are obtained for other closely related species.
\end{abstract}

Friesella schrottkyi / seminal vesicle / morphology / holocrine secretion / Hymenoptera / reproductive system

\section{INTRODUCTION}

The Meliponini tribe (Apidae), which includes Friesella schrottkyi (Friese), is distributed in all tropical and subtropical regions of the Southern Hemisphere (Michener, 2000; Silveira et al., 2002). Besides the use of these species to enhance agricultural production, the interest in studying and preserving these species derives from their importance as pollinators of native vegetation. In order to protect a species, it is important to

Corresponding author: J. Lino-Neto, linoneto@ufv.br

* Manuscript editor: Klaus Hartfelder understand its reproductive behavior, as well as its systematics. Despite the importance of the stingless bees, there are many unresolved points related to their reproduction, taxonomy and phylogeny (Rasnitsyn, 1988; Dowton and Austin, 1994; Dowton et al., 1997; Ronquist et al., 1999).

Secretions from accessory glands of the male reproductive system have been associated with reproductive success in many species. Some functions of these secretions are: spermatozoon nutrition, helping spermatozoon displacement along the ducts and inducing post-copula behavior in females (Gillott, 2003). In species that form spermatophores, sperm are packed by secretory 
materials from the glands before to their transfer to the female (Chen, 1984; Sturm, 2003). Therefore, it is noteworthy that Meliponini bees do not have such glands (Kerr, 1948; Ferreira et al., 2004).

Measuring almost $3 \mathrm{~mm}$ in length, $F$. schrottkyi is a small bee that is distributed throughout the Brazilian southeast (Silveira et al., 2002). These bees are not aggressive; their colonies are small with approximately 300 individuals and irregular combs are found inside the colonies. Males of F. schrottkyi are produced throughout the year from queen or workers' unfertilized eggs (Velthuis et al., 2005). Friesella is a monotypic genus (Camargo and Pedro, 2008) that is closely related to another Meliponini genus: Plebeia (Michener, 1990, 2000).

This study describes morphophysiological aspects of the male reproductive system of $F$. schrottkyi during sexual maturation, and aspects related to sperm release from the testes, with the intention of contributing to the study of reproductive physiology.

\section{MATERIAL AND METHODS}

To obtain adult males of known ages, from 0 (just emerged) to 14 days, combs were taken from colonies of F. schrottkyi, maintained in the Central Apiary of the Universidade Federal de Viçosa (Viçosa, MG, Brazil), and conditioned in Petri dishes. These were maintained in BOD at $28.7^{\circ} \mathrm{C}$. They were inspected daily and the males were marked with a nontoxic paint for later age identification. As each adult emerged, the individuals were transferred to a "colony" previously mounted with workers, also maintained in BOD, and fed daily with a sucrose solution and pollen taken from colonies at the apiary.

\subsection{Histology}

Reproductive systems were dissected in cacodylate buffer ( $\mathrm{pH} 7.2$ ), fixed for $12 \mathrm{~h}$ in $2.5 \%$ glutaraldehyde and post-fixed in $1 \%$ osmium-tetroxide for $2 \mathrm{~h}$. Dehydration was carried out in a progressively increasing alcoholic series $(50,70,90,95$, $100 \%$ ) and organs were subsequently embedded in historesin. Thin sections were stained with toluidine blue. They were mounted with $50 \%$ sucrose or with Entellan (Merck), examined and photographed with a photomicroscope, Olympus CX31.

For lipid removal, seminal vesicles were fixed for $12 \mathrm{~h}$ in $2.5 \%$ glutaraldehyde, dehydrated to absolute alcohol and xylene, re-hydrated and postfixed in osmium tetroxide. Thin sections were stained with toluidine blue.

\subsection{Histochemistry}

Reproductive systems were dissected in cacodylate buffer ( $\mathrm{pH}$ 7.2), fixed in Stefanini liquid (Stefanini et al., 1967), dehydrated in an alcoholic series and embedded in historesin. Histological sections were submitted to: (1) PAS (Junqueira and Junqueira, 1983) for neutral carbohydrate detection; (2) Alcian Blue pH 2.5 and $\mathrm{pH} 0.5$ (Bancroft and Stevens, 1996) for acid glycoconjugates and (3) Xylidine Ponceau (Mello and Vidal, 1980) for protein detection. They were also submitted to acid and alkaline phosphatase detection (Bancroft and Stevens, 1996).

To identify the nucleus, some histological slides were stained for $15 \mathrm{~min}$ in $0.2 \mu \mathrm{g} / \mathrm{mL}$ 4,6-diamino-2-phenylindole (DAPI) in phosphate buffered saline. They were examined with an epifluorescence microscope (Olympus, BX60), equipped with a BP 360-370 nm excitation filter.

\subsection{Transmission Electron Microscopy (TEM)}

Reproductive systems were fixed in a solution containing $2.5 \%$ glutaraldehyde, $0.2 \%$ picric acid, $3 \%$ sucrose and $5 \mathrm{mM} \mathrm{CaCl}_{2}$ in $0.1 \mathrm{M}$ cacodylate buffer, $\mathrm{pH}$ 7.2. The material was post-fixed in $1 \%$ osmium-tetroxide in the same buffer for $2 \mathrm{~h}$. Dehydration was carried out in acetone and embedding of the organs in epon. Ultrathin sections were stained with $2 \%$ uranyl acetate and $0.2 \%$ lead citrate and observed with the Zeiss Leo 906 transmission electron microscope, at $60 \mathrm{kV}$.

\section{RESULTS}

\subsection{Reproductive system}

The reproductive system of $F$. schrottkyi males consists of two testes, each made up of four follicles. From each follicle originates an efferent duct, and the four tubular structures 


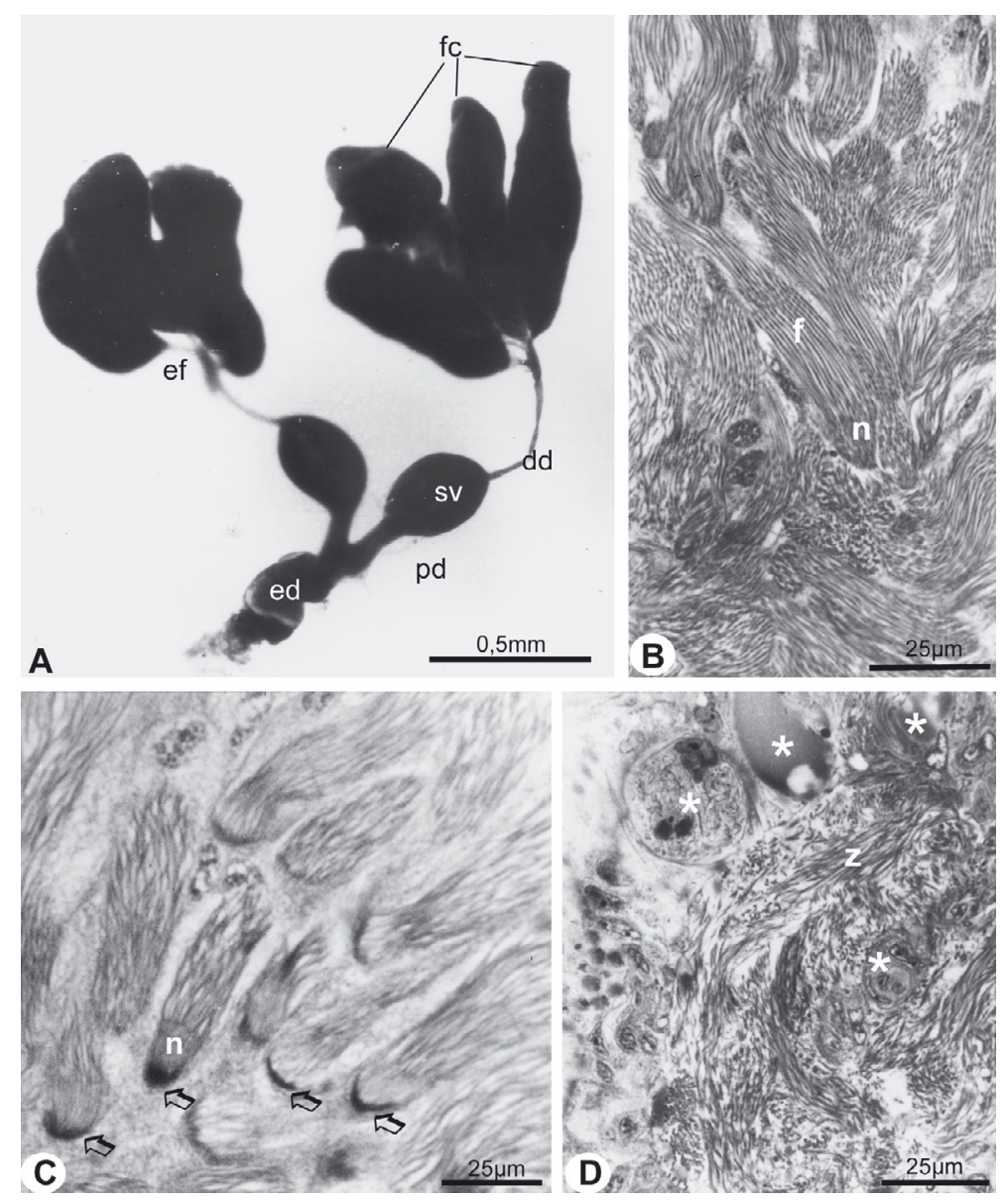

Figure 1. (A) Male reproductive system of a F. schrottkyi four day-old adult, (B-D) histology of testicular follicles: (B) detail of a cyst of a five day old adult, with the nuclear (n) and flagellar (f) regions identified; (C) nine day-old adult spermatozoa cysts, with the glycoprotein cap (open arrows) already formed; (D) degenerating follicle of a 12 day-old adult has free spermatozoa (z); note degenerative figures (asterisks). (dd) Pre vesicular deferent duct, (ed) ejaculatory duct, (ef) efferent duct, (fc) follicles, (pd) post vesicular deferent duct, (sv) seminal vesicle.

join to form the deferent duct. Near the abdominal extremity, the two resulting deferent ducts, discharged in a short ejaculatory duct. The deferent ducts present a differentiated region, the seminal vesicle, where the sperm are stored until copulation. Therefore, the deferent ducts can be separated in pre- and postvesicular portions. In immature males (young adults), testicular follicles are elongated and curved (Fig. 1A), while in mature adult males (around 14 days after emergence), the follicles are completely degenerated.

\subsection{Spermatogenesis and spermatozoan release}

The spermatozoa of $F$. schrottkyi have synchronized development; that is, all spermatozoa mature at the same time. When F. schrottkyi males emerge, their spermiogenesis is already finished, with spermatozoa already elongated and organized in cysts, their heads pointing to the efferent duct (Fig. 1B). No changes were observed in their development until approximately the ninth day, which 
is marked by the formation of a glycoprotein cap which encloses the spermatozoan heads in each cyst (Fig. 1C) (Tab. I). From this stage on, the testicular cysts began to disorganize and separated spermatozoa were found in the follicles (Figs. 1D, 2A). On the 12th day, the follicles showed some degenerative figures and neither any bundles of spermatozoa nor their remains were observed (Fig. 1D). Spermatozoa were found in the seminal vesicle only after the ninth day (Fig. 2B). Rarely were spermatozoa bundles or bundle fragments observed in the seminal vesicle, since the spermatozoa are mostly separated when they reach the deferent duct (Fig. 2C).

\subsection{Seminal vesicle}

In F. schrottkyi, the seminal vesicle consists of a monolayer of prismatic epithelial cells, externally covered by a muscular layer (Figs. 3A, B). During sexual maturation, the epithelium undergoes drastic changes (Tab. I).

In newly emerged individuals, the seminal vesicle lumen is reduced (Fig. 3A), epithelial cell height was approximately $50 \mu \mathrm{m}$ and basal membrane infoldings supplied anchorage structures (Fig. 3C). Adhesion junctions were observed in the apical portion of the epithelium (Fig. 3D). Nuclei, positioned in the basal third of the cell, showed loose chromatin and at least one strongly staining nucleolus. The chromatin was not condensed during the entire maturation period. In just-emerged adults, the epithelial cells had a few and irregular microvilli (Fig. 3D). In one day old adults, the epithelial cells present bubble-like apical projections (Fig. 3B).

From the third day on, the seminal vesicle epithelium is very irregular, with large apical projections. In general, the nuclei are included in these projections, with no evident chromatin alteration (Figs. 4A-C). These projections are irregular and present constrictions between them and their cytoplasmic bases (Fig. 4C). Beside these cells, with apical projections, are some epithelial regions with half of the original epithelial height (Fig. 4B). The apical projections are released in the vesicle lumen, originating the cell fragments found during this phase, which characterize holocrine secretion
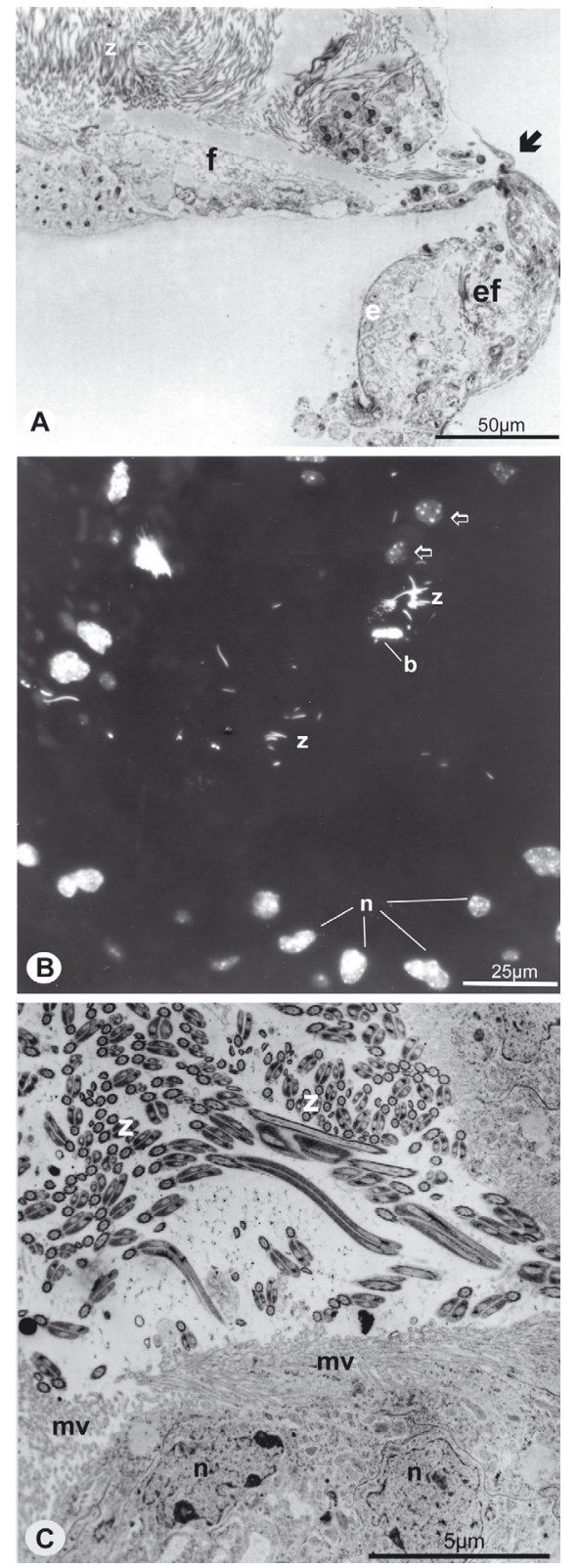

Figure 2. (A) Longitudinal section of the transition (arrow) between a testicular follicle (f) and its efferent duct (ef), of a 10 day-old adult, (B) DAPI of a 9 day-old adult seminal vesicle, with some luminal cell structures (open arrows), some free spermatozoa (z) and some sperm bundles (b), (C) TEM of an efferent duct of a 14 day-old adult, with free spermatozoa in the lumen. (e) Efferent duct epithelium, (mv) microvilli, (n) nuclei of epithelial cells, (z) free spermatozoa in the follicle. 
Table I. Main characteristics of the male reproductive systems of $F$. schrottkyi and their development during sexual maturation.

\begin{tabular}{|c|c|c|}
\hline \multirow[t]{2}{*}{ AGE } & \multicolumn{2}{|c|}{ CHARACTERISTICS } \\
\hline & Testes & Seminal vesicle \\
\hline $\begin{array}{l}\text { Just } \\
\text { emerged }\end{array}$ & Spermiogenesis completed & $\begin{array}{l}\text { Seminal vesicle lumen reduced, epithelium } \\
50 \mu \mathrm{m} \text { high, basal nuclei, few membranous } \\
\text { inclusions }(<1 \mu \mathrm{m} \text { diameter }) \text {, lipid droplets }\end{array}$ \\
\hline $3-8$ days & No changes & $\begin{array}{l}\text { Seminal vesicle lumen increased, large } \\
\text { epithelial apical projections containing } \\
\text { nuclei, holocrine secretion, larger } \\
\text { membranous inclusions (irregular shape), } \\
\text { lipid droplets }\end{array}$ \\
\hline 9 days & $\begin{array}{l}\text { Formation of the glycoprotein } \\
\text { cap, bundle disorganization, } \\
\text { sperm individualized inside } \\
\text { testes }\end{array}$ & $\begin{array}{l}\text { Sperm arrive in seminal vesicles, holocrine } \\
\text { secretion not observed, lipid droplets }\end{array}$ \\
\hline 14 days & Testes degenerated & $\begin{array}{l}\text { Seminal vesicle full of spermatozoa, } \\
\text { epithelium } 25 \mu \mathrm{m} \text { high, apical nuclei, large } \\
\text { membranous inclusions ( } 2 \mu \mathrm{m} \text { diameter }), \\
\text { fused membranous inclusions, lipid } \\
\text { droplets }\end{array}$ \\
\hline
\end{tabular}

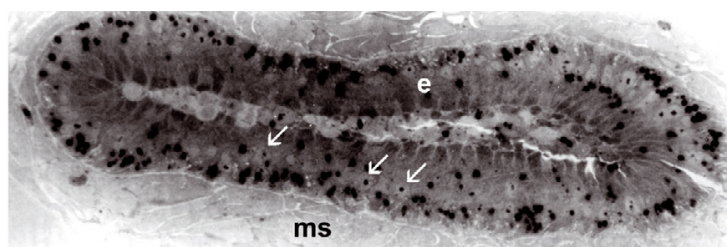

A
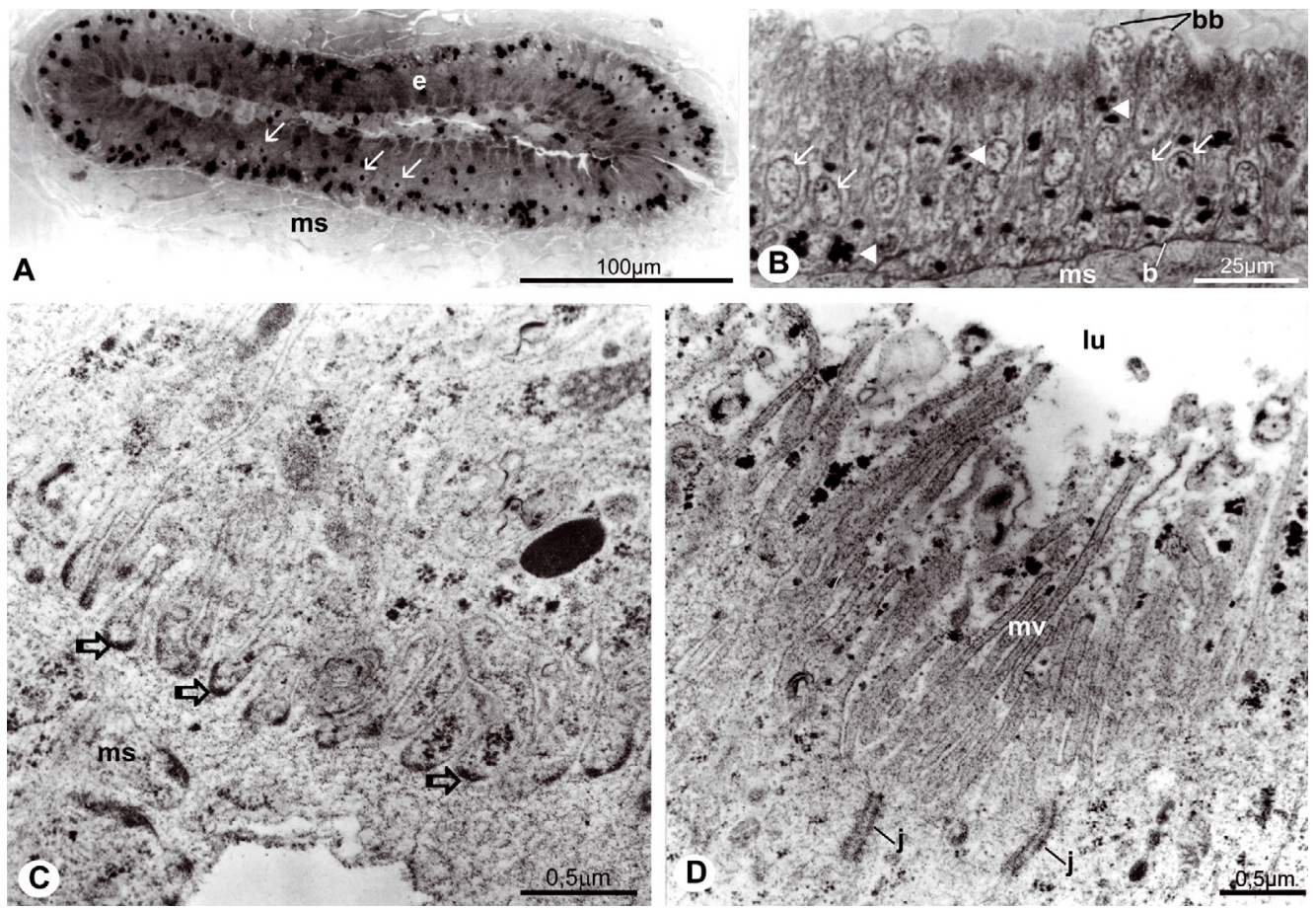

Figure 3. (A-B) Histology of adult seminal vesicles: (A) just-emerged, with reduced lumen, (B) epithelial detail of a one day-old adult with bubble-like projections (bb), (C-D) TEM of the seminal vesicle of one day old adult; (C) basal cellular portion, note anchorage structures (open arrows) in cellular infoldings, (D) apical cell portion. (b) basal layer, (e) seminal vesicle epithelium, (j) cell junctions, (lu) seminal vesicle lumen, (ms) muscular layer, (mv) microvilli, (arrow) epithelial cell nuclei, (arrowhead) dark lipid droplets. 

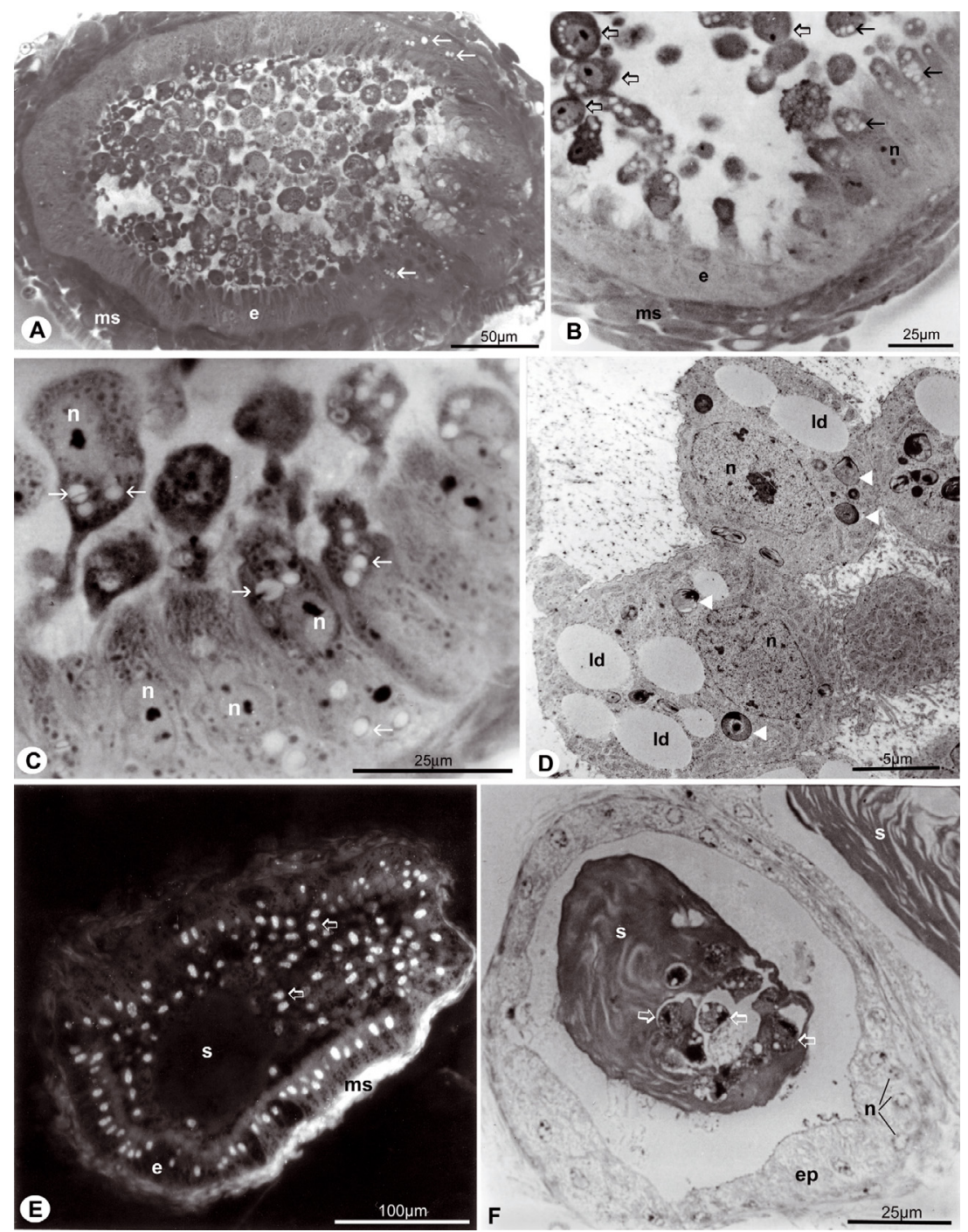

Figure 4. (A-C) Histological sections, mounted with Entellan, of four day-old adult's seminal vesicles. Note: (A) the lumen, full of cellular fragments, (B) a prismatic epithelium region beside a cubic epithelium region, (C) epithelial cells with apical projections, containing nuclei, (D) TEM of four day-old adult luminal cell fragments, (E-F) histological sections: (E) of a seminal vesicle stained with DAPI to identify cell fragment nuclei. Notice the area occupied by secretion (s) that flowed from the deferent duct; (F) a post vesicular deferent duct, with cell fragments embedded in the PAS positive secretion. (e) vesicle epithelium, (ep) deferent duct epithelium, (ld) lipid droplets, (ms) muscular layer, (n) nuclei, (arrows) clear lipid droplets, (open arrows) luminal nucleated cellular structures, (arrowheads) membranous inclusions. 
(Fig. 4A).The cell fragments include a large volume of cytoplasm (Fig. 4D), with the same characteristics as the epithelial cell cytoplasm. Most of the luminal cell fragments have a nucleus (Figs. 4D, E), with no distinguishing morphological features in relation to the epithelial cells. These structures are seen in the seminal vesicle lumen up to an age of nine days, when the spermatozoa begin to arrive (Fig. 2B). Sometimes, cellular structures were observed in the post-vesicular deferent duct lumen, embedded in a PAS positive, fibrous secretion (Fig. 4F).

In 14 day-old adults, the seminal vesicle lumen was full of sperm and none of the cell structures, which had filled the lumen till the ninth day, were observed (Fig. 5A). The seminal vesicle epithelium is regular in height, measuring approximately $25 \mu \mathrm{m}$, with nuclei located in the apical third of the cell (Fig. 5B).

The acid and alkaline phosphatase tests were negative in the epithelial cells and cell fragments. No mitotic figures or stem cell nests were observed during the entire period studied.

\subsection{Lipid droplets}

In all ages, big lipid droplets were observed in the epithelial cells of the seminal vesicles. These droplets had variable sizes, some of them reaching $4 \mu \mathrm{m}$ in diameter. They were brown when mounted with $50 \%$ sucrose (Figs. 3A, B and 5A, B), but were transparent when mounted with Entellan (Figs. 4B, C) and empty after lipid removal (with xylene). These droplets were also observed in the cell structures of the seminal vesicle lumen (Figs. 4B, C) and in the post-vesicular deferent duct (Fig. 4F). They were negative to histochemical tests for sugar and protein detection.

Transmission electron microscopy revealed that these droplets were not surrounded by membranes and consisted of homogeneous, low-density material (Figs. 4D, 6A-C and 7A).

\subsection{Membranous inclusions}

Transmission electron microscopy revealed the presence of a great quantity of
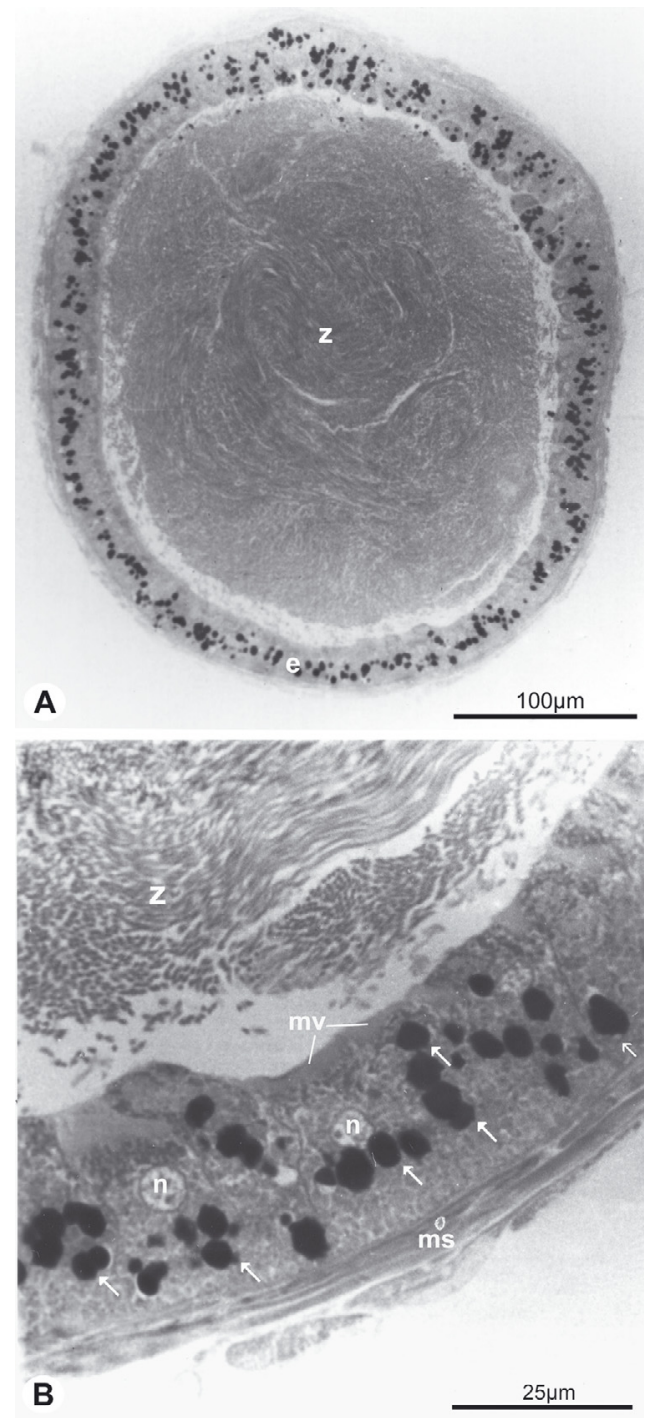

Figure 5. Histology of 14 day-old adult's seminal vesicles: (A) notice the vesicle full of free spermatozoa (z) and no luminal cellular structures, (B) epithelial detail. Notice the cubic cells with regular microvilli (mv). (e) vesicle epithelium, (ms) muscular layer, (n) nuclei, (arrows) lipid droplets.

membranous inclusions. These inclusions were made of heterogeneous material and were present in the epithelial cells and luminal cell structures in males of all ages (Figs. 4D, $6 \mathrm{~A}-\mathrm{F}$ and $7 \mathrm{~A}, \mathrm{~B})$. The content and diameter of these inclusions varied during maturation: in recently emerged adults they are scattered, 

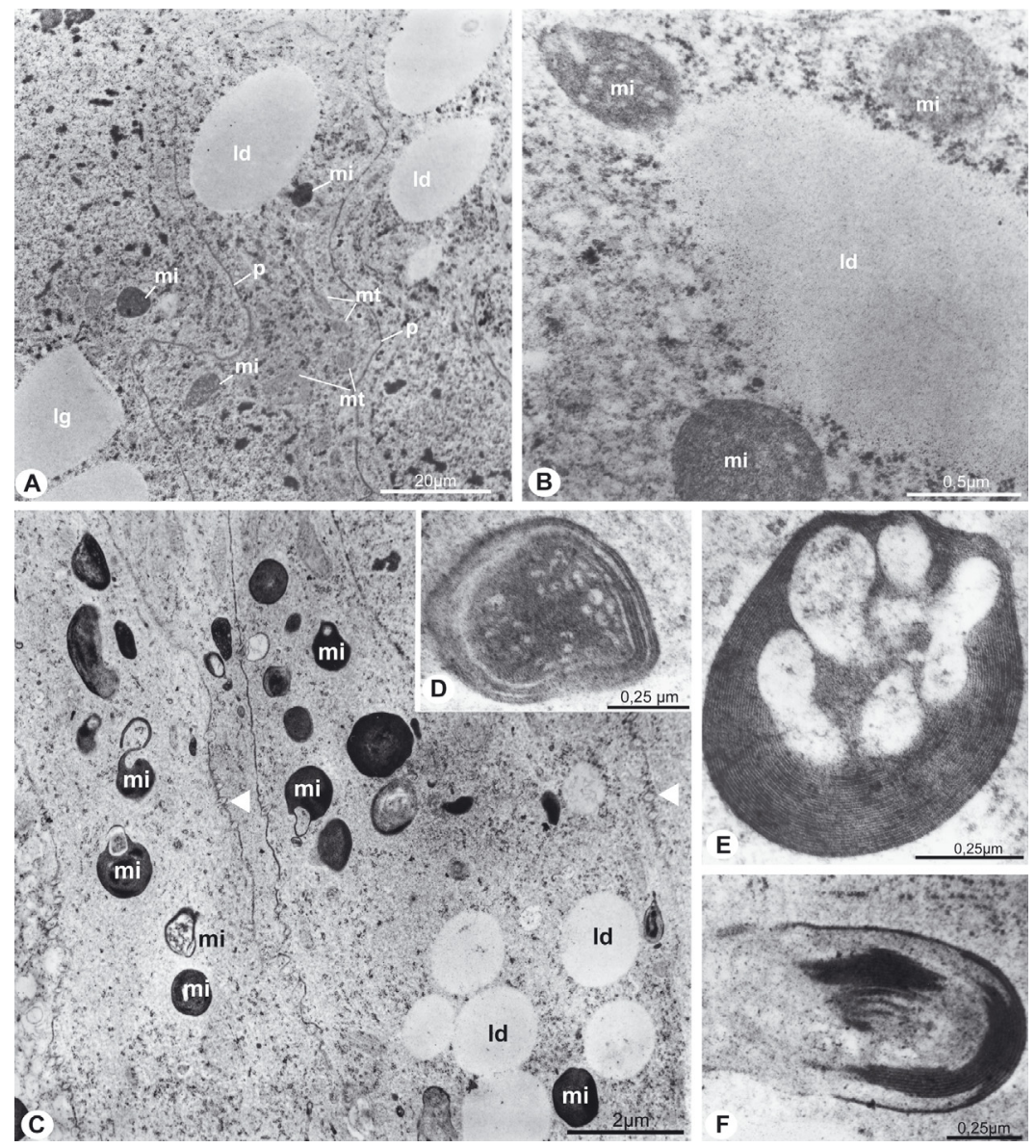

Figure 6. TEM of seminal vesicle epithelium of adults with: (A-B) one day of age, (B) detail of membranous inclusions and lipid droplets; (C-F) Four day-old adults, (D-F) membranous inclusions in higher magnification. (ld) lipid droplets, (mi) membranous inclusions, (mt) mitochondria, (p) plasmatic membranes, (arrowheads) septated junctions.

with less than $1 \mu \mathrm{m}$ in diameter and their content is electron dense with some electron lucid regions (Figs. 6A, B). These inclusions are more common in adults of about four days of age, where they are bigger and sometimes irregular in shape (Fig. 6C). They consist of totally or partially layered electron dense material, which covers irregular electron lucid figures, alternating with areas of median electron density (Figs. 6D-F). In sexually mature males, the inclusions can reach about $2 \mu \mathrm{m}$, and contain mostly medium electron dense material, with electron lucent regions and some layered electron dense material (Figs. 7A, B). At this stage, it is easy to observe membranous inclusions that appear to have fused (Fig. 7B).

\section{DISCUSSION}

The male reproductive system of F. schrottkyi is similar to that observed in other Meliponini bees and corresponds to type IV described by Ferreira et al. (2004), which is chiefly characterized by the absence of accessory glands.

In F. schrottkyi, spermatozoa reach the seminal vesicle only nine days after adult emergence, which differentiates this species 


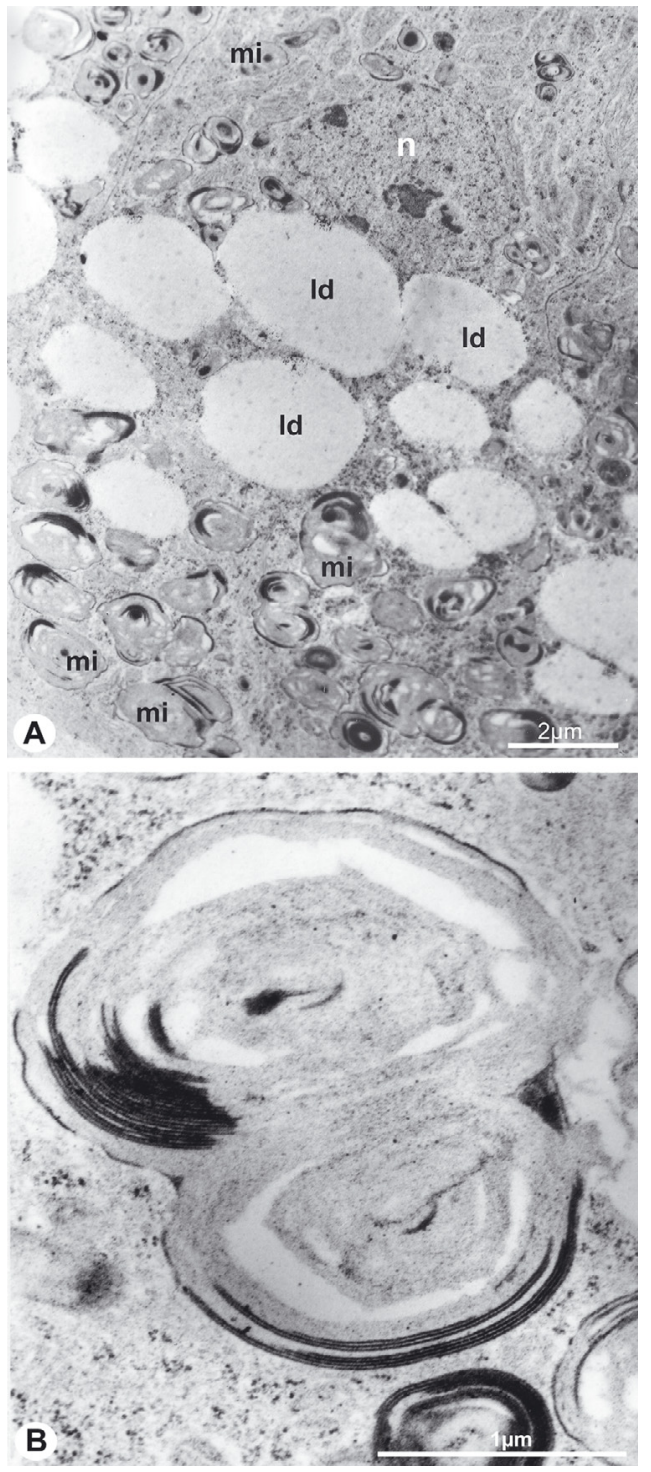

Figure 7. (A-B) TEM of 14 day-old adult seminal vesicle, (B) detail of a membranous inclusion that seems to be fused. (ld) lipid droplets, (mi) membranous inclusions, (n) nuclei.

from other known Meliponini. In Melipona mondury (Smith) (Lima et al., 2006) and Scaptotrigona xanthotricha (Moure) (Araújo, 2005), spermatozoa can be observed in the seminal vesicle on the fourth day, while in $M$. quadrifasciata (Lepeletier), they occur on the seventh day (Camargo, 1984). It is important to note that even with the longer period that F. schrottkyi spermatozoa take to leave testes, the sexual maturity of these bees is reached almost at the same age as M. mondury (Lima et al., 2006), S. xanthotricha (Araújo, 2005), Apis mellifera (Linnaeus) (Snodgrass, 1978) and Bombus terrestris (Linnaeus) (Tasei et al., 1998), that is around 12 to 15 days after emergence.

As a rule, Aculeata release their spermatozoa from the testes in bundles, and they are individualized only in the seminal vesicles (Cruz-Landim, 2001; Zama et al., 2001, 2004, 2005; Moreira et al., 2004). On the other hand, spermatozoa of 'symphyta' wasps are not observed freed from spermatodesmata (Quicke et al., 1992; Schiff et al., 2001; Lino-Neto et al., 2008). However, in F. schrottkyi most of the bundles are disorganized already in the testes, therefore bundles or even bundle fragments are rarely observed in the seminal vesicles. This characteristic is probably related to the long period required for spermatozoan release from the testes, which must influence the spermatozoan maturation and activation process. Early bundle disorganization in the testes may also be related to the smaller size of the $F$. schrottkyi glycoprotein cap when compared with other species, or to some difference in its composition.

There are only few reports describing insect seminal vesicle morphology (e.g. Davis, 1968; Lai-Fook, 1982a; Couche and Gillott, 1988; Viscuso et al., 1999; Fausto et al., 2000), and only a minor set of these deals with Hymenoptera. The most complete papers for this order are those concerning Camponotus spp. (Wheeler and Krutzsch, 1992), Melipona bicolor (Lepeletier) (Dallacqua and Cruz-Landim, 2003), M. mondury (Lima et al., 2006) and S. xanthotricha (Araújo et al., 2005). In Friesella schrottkyi, the general morphology of the seminal vesicle is similar to that of other Meliponini. However some characteristics of this species have not been observed in any other Hymenoptera.

Secretory activity has been already reported in ducts of the male reproductive system of different insects. Apocrine secretion was observed in the seminal vesicles of Phasmoidea (Viscuso et al., 2005) and Orthoptera 
(Viscuso et al., 1999) and in Lepidoptera ejaculatory simplex (Lai-Fook, 1982b; Amaldoss, 1990). Holocrine secretion was reported in Drosophila accessory glands (Perotti, 1971), in the ejaculatory duct of Musca domestica (Leopold, 1970; Riemann, 1973) and in the ejaculatory simplex of one Lepidoptera (Amaldoss, 1990). In seminal vesicles, holocrine secretion was suggested for two Orthoptera species based on different epithelium heights (Viscuso et al., 1999). In a Camponotus ant this type of secretion was suggested by the epithelium degeneration in males collected during nuptial flight (Forbes, 1954), however, it is not clear if this observation is related only to male senescence.

Some authors have already described bees' seminal vesicle epithelial cells as changing from cylindrical to cubic and presenting apical bubble-like projections (apocrine secretion), during sexual maturation (Cruz-Landim and Cruz-Hofling, 1969; Araújo, 2005). However, drastic cellular changes, such as long apical projections and many nucleated cell fragments in the seminal vesicle lumen, have not yet been observed elsewhere in insects.

Mature males of $M$. bicolor (Dallacqua and Cruz-Landim, 2003) and S. xanthotricha (Araújo et al., 2005) did not present any secretory characteristics in their vesicle epithelium. But, in F. schrottkyi the seminal vesicle epithelium could be described as secretory during all stages of adult life, especially between the fourth and ninth day after emergence, when cell structures were observed in the vesicle lumen, which represents holocrine secretion. We suppose that the fibrous secretion found in the post-vesicular deferent ducts may play an important role in the seminiferous secretions. Despite the eventual presence of this secretion in the seminal vesicle, this secretion is apparently produced in the postvesicular deferent duct and can sometimes flow back into the seminal vesicle.

It is possible to say that the big inclusions observed in the vesicle epithelium are lipid droplets, since they did not respond to tests for proteins and sugar and were preserved only after osmium post-fixation. Under the transmission electron microscope they were electronlucid and showed no surrounding membrane.
The presence of large lipid droplets has never been described in the seminal vesicle epithelium of other insects.

Possibly, the membranous inclusions revealed with electron microscopy, in F. schrottkyi vesicle epithelium, are analogous to those observed in S. xanthotricha (Araújo et al., 2005), M. bicolor (Dallacqua and Cruz-Landim, 2003) and Camponotus spp. (Wheleer and Krutzsch, 1992). However, in these species the inclusions were observed only in sexually mature adults. These authors proposed that the inclusions must be related to secretion, or spermiophagy. Membranous inclusions ("myelin figures") were also reported in the apocrine secretion of ejaculatory simplex in Lepidoptera and were related to spermatophore formation (Lai-Fook, 1982b). In F. schrottkyi, these inclusions were observed even in immature males and undergo morphological changes during sexual maturation. Since they did not react to acid phosphatase tests, and are also present in the cell fragments (holocrine secretion), these inclusions probably are components of this holocrine secretion.

The "late" release from the testes of already separated spermatozoa, freed from the bundle arrangements, as well as the presence of holocrine secretion in seminal vesicle, with two types of inclusions (lipidic and membranous) in the vesicle epithelium during all stages, are characteristics that differentiate $F$. schrottkyi from other Hymenoptera, including closely related genera within the Meliponini. Possibly these morphophysiological differences in the $F$. schrottkyi sexual maturation of males may reflect the evolutionary history of the group. Therefore, the study of these structures in other bee genera, such as Plebeia, would be interesting for comparisons between genera as well as to explain the reproductive physiology and systematics of these Hymenoptera.

\section{CONCLUSIONS AND FUTURE AIMS}

In order to understand spermatozoon maturation and activation in $F$. schrottkyi, the long period between adult emersion and the 
beginning of spermatozoan release from the testes must be investigated. For example, in this species the flow through the ducts must be intense because of the "late" beginning of spermatozoan release and this could be related to a differentiated muscular sheath of the prevesicular deferent duct. The dynamics of the spermatozoa before reaching the seminal vesicle also must be investigated.

As the seminal vesicle epithelium presents holocrine secretion and we did not observe mitosis or stem cell nests in this epithelium, further investigation must be undertaken to explain how it regenerates, or even if the remaining cytoplasmatic fragments adhering to the basal lamina are efficient for epithelium maintenance. Also the biochemical characteristics of this holocrine secretion should be investigated in the future, in order to compare this secretion with that of accessory glands of other insects.

\section{ACKNOWLEDGEMENTS}

The authors would like to acknowledge Dr. Lucio A.O. Campos (UFV) for the invaluable support given during the development of this work as well as two anonymous referees for very helpful comments on manuscript. This research had the financial support of the Brazilian agencies CAPES, FAPEMIG and FAPESP.

Nouvelles caractéristiques de l'organe reproducteur mâle chez l'abeille mélipone Friesella schrottkyi (Hymenoptera : Apidae) : développement histologique et physiologique au cours de la maturation sexuelle.

Meliponi / Friesella schrottkyi / vésicule séminale / organe reproducteur/sécrétion holocrine / morphologie

Zusammenfassung - Neue Merkmale des männlichen Reproduktiossystems der stachellosen Biene Friesella schrottkyi Friese (Hymenoptera: Apidae): Histologische und physiologische Differenzierung im Verlauf der sexuellen Reifung. Diese Studie beschreibt mittels Licht- und Elekronenmikroskopie die morphologischen Veränderungen im Verlauf der sexuellen Reifung des männlichen Reproduktionssystems der stachellosen Biene Friesella schrottkyi und kann damit wichtige
Anhaltspunkte zum Verständnis der Reproduktionsphysiologie dieser Bienen liefern.

Bezeichnend für das männliche Reproduktionssystem von $F$. schrottkyi ist das Fehlen akzessorischer Drüsen und die Tatsache, dass die Spermiogenese bereits mit dem Schlüpfen der Imagines abgeschlossen ist (Abb. 1). Spermien erreichen die Samenblasen jedoch erst neun Tage nach dem Schlupf. Die Spermien verlassen die Hoden dabei bereits als Einzelspermien und nicht in Bündeln, wie bei anderen Bienen, und demenstprechend findet man in den Samenblasen auch keine Bündel und nur selten Bündelfragmente (Abb. 2).

Die Samenblasen weisen im Verlauf der sexuellen Reifung starke Veränderungen auf. Bei frischgeschlüpften Männchen ist das Lumen noch stark reduziert und das Epithel ist $50 \mu \mathrm{m}$ hoch (Abb. 3). $\mathrm{Ab}$ dem dritten Imaginaltag weisen die Epithelzellen große apikale Ausläufer auf, in denen die Zellkerne und eine grosse Menge an Cytoplasma zu finden sind. Die apikalen Ausläufer öffnen sich und die Zellfragmente, die durch diese kolokrine Sekretion produziert werden, füllen das Lumen der Samenblase. Beim Vergleich der Zellkerne und des Cytoplasmas im Sekret mit den entsprechenden Bestandteilen der Epithelzellen konnten wir keine Unterschiede erkennen. Solche Zellfragmente sind auch in den postvesikulären Abschnitten des Reproduktionsstrakts zu finden (Abb. 4). In den Samenblasen sind die Zellfragmente noch bis zum neunten Tag zu sehen, d.h. bis zur Ankunft der Spermien. Ab etwa 14 Tagen sind die Samenblasen mit Spermien gefüllt und keine Zellfragmente mehr nachweisbar. Das Epithel der Samenblase ist in dieser Phase normal strukturiert und etwa $25 \mu \mathrm{m}$ hoch (Abb. 5).

Während dieser ganzen Phase enthalten die Epithelzellen Lipidtropfen und Membraneinschlüsse. Die Komplexität dieser Membraneinschlüsse variiert im Verlauf der sexuellen Reifung (Abb. 6 und 7). Lipidtropfen und Membraneinschlüsse sind auch in den Zellfragmenten im Lumen zu finden und bilden einen Teil der holokrinen Sekretion.

Obwohl bei F. schrottkyi die Spermien die Samenblasen erst relativ spät erreichen, ist die sexuelle Reifung zum gleichen Zeitpunkt abgeschlossen, wie bei anderen Bienen. Die Individualisierung der Spermien bereits in den Hoden ist ein Merkmal, in dem sich diese Art von anderen Aculeaten unterscheidet (Moreira et al., 2004). Auch eine holokrine Sekretionsbildung durch das Epithel der Samenblasen ist bisher bei keiner anderen stachellosen Biene beschrieben (Dallacqua and Cruz-Landim, 2003; Araújo et al., 2005). Weitere vergleichende Untersuchungen an stachellosen Bienen sind erforderlich, um diese bei $F$. schrottkyi erhobenen neuen Befunde vergleichend verstehen zu können.

Friesella schrottkyi / Samenblase / Morphologie / holokrine Sekretion / Hymenoptera / Reproduktionssystem 


\section{REFERENCES}

Amaldoss G. (1990) Fine structure of the regional differentiation of the ductus ejaculatorius simplex (EJ1, EJ2, EJ3) along with the role of their secretios in the sperm activation and motility in two Noctuid species, Heliothis armigera (Hiibner) and Spodoptera litura (Fabricius) (Lepidoptera). II. Fine structure and function of simplex 2 (EJ2), Proc. Indian Acad. Sci. 99, 19-38.

Araújo V.A. (2005) Universidade Federal de Viçosa, Master's thesis.

Araújo V.A., Zama U., Neves C.A., Dolder H., Lino-Neto J. (2005) Ultrastructural, histological and histochemical characteristics of the epithelial wall of the seminal vesicle of mature Scaptotrigona xanthotricha Moure males (Hymenoptera, Apidae, Meliponini), Braz. J. Morphol. Sci. 22, 193-201.

Bancroft J.D., Stevens A. (1996) Theory and practice of histological techniques, Churchill Livingstone, New York, p. 766.

Camargo C.A. (1984) Spermatozoa numbers and migration to the seminal vesicle in haploid and diploid males of Melipona quadrifasciata Lep, J. Apicult. Res. 23, 15-17.

Camargo J.M.F., Pedro S.R.M. (2008) Meliponini Lepeletier, 1836, in: Moure J.S., Urban D., Melo G.A.R. (Eds.) Catalogue of Bees (Hymenoptera, Apoidea) in the Neotropical Region - online version. Available at http://www.moure.cria.org.br/ catalogue, accessed Jul/27/2009.

Chen P.S. (1984) The functional morphology and biochemistry of insect male accessory glands and their secretions, Annu. Rev. Entomol. 29, 233 255.

Couche G.A., Gillott C. (1988) Development of secretory activity in the seminal vesicle of the male migratory grasshopper, Melanoplus sanguinipes (Fabr.) (Orthoptera: Acrididae), Int. J. Insect Morphol. 17, 51-61.

Cruz-Landim C. (2001) Organization of the cysts in bee (Hymenoptera: Apidae) testes: number of spermatozoa per cyst, Iheringia 91, 183-189.

Cruz-Landim C., Cruz-Hofling M.A. (1969) Observações sobre a ultraestrutura do vaso deferente de Apis mellifera L, Rev. Bras. Biol. 20, 181-190.

Dallacqua R.P., Cruz-Landim C. (2003) Ultrastructure of the ducts of the reproductive tract of males of Melipona bicolor bicolor Lepeletier (Hymenoptera, Apinae, Meliponini), Anat. Histol. Embryol. 32, 276-281.

Davis F.M. (1968) Morphology of the reproductive systems of the southwestern corn borer, Diatraea grandiosella, Ann. Entomol. Soc. Am. 61, $1143-$ 1147.

Dowton M., Austin A.D. (1994) Molecular phylogeny of the insect order Hymenoptera: Apocritan relationships, Proc. Natl. Acad. Sci. (USA) 91, 99119915.
Dowton M., Austin A.D., Dillon N., Bartowsky E. (1997) Molecular phylogeny of the apocritan wasps: the Proctotrupomorpha and Evaniomorpha, Syst. Entomol. 22, 245-255.

Fausto A.M., Gambellini G., Taddei A.R., Maroli M., Mazzini M. (2000) Ultrastructure of the seminal vesicle of Phlebotomus perniciosus Newstead (Diptera, Psychodidae), Tissue Cell 32, 228-237.

Ferreira A., Abdalla F C., Kerr W.E., Cruz-Landim C. (2004) Comparative anatomy of the male reproductive internal organs of 51 species of bees, Neotrop. Entomol. 33, 569-576.

Forbes J. (1954) The anatomy and histology of the male reproductive system of Camponotus pennsylvanicus DeGeer (Formicidae, Hymenoptera), J. Morphol. 95, 523-555.

Gillott C. (2003) Male accessory gland secretions: Modulators of female reproductive Physiology and Behavior, Annu. Rev. Entomol. 48, 163-184.

Junqueira L.C.U., Junqueira M.M.S. (1983) Basic techiniques on citology and histology (Técnicas básicas de citologia e histologia), Livraria Editora Santos, São Paulo, p. 123.

Kerr W.E. (1948) Estudos sobre o gênero Melipona, Escola superior de Agricultura Luis de Queiroz, USP, Doctoral thesis.

Lai-Fook J. (1982a) The vasa deferentia of the male reproductive system of Calpodes ethlius (Hesperiidae, Lepidoptera), Can. J. Zool. 60, 1172-1183.

Lai-Fook J. (1982b) Structure of the noncuticular simplex of the internal mele reproductive tract of Calpodes ethlius (Hesperiidae, Lepidoptera), Can. J. Zool. 60, 1184-1201.

Leopold R.A. (1970) Cytological and cytochemical studies on the ejaculatory duct and accessory secretion in Musca domestica, J. Insect Physiol. 16, 1859-1872.

Lima M.A.P., Lino-Neto J., Campos L.A.O. (2006) Sexual maturation in Melipona mondury males (Apidae: Meliponini), Braz. J. Morphol. Sci. 23, 369-375.

Lino-Neto J., Dolder H., Mancini K., Mercati D., Dallai R. (2008) The short spermatodesm of Arge pagana (Hymenoptera: symphyta), Tissue Cell 40, 185-193.

Mello M.L.S., Vidal B.C. (1980) Práticas de Biologia Celular, Edgard Blucher, Campinas, p. 69.

Michener C.D. (1990) Classification of the Apidae (Hymenoptera), The Univ. Kansas Sci. Bull. 54, $75-164$.

Michener C.D. (2000) The Bees of the World. Johns Hopkins University press, Baltimore, p. 913.

Moreira J., Zama U., Lino-Neto J. (2004) Release behavior and phylogenetic significance of spermatozoa in bundles in the seminal vesicle during sexual maturation in Aculeata (Hymenoptera), Braz. J. Morphol. Sci. 21, 185-189. 
Perotti M.E. (1971) Microtubules as components of Drosophila male paragonia secretion: An electron microscopic study, with enzymatic tests, J. Submicrosc. Cytol. 3, 255-282.

Quicke D.L.J., Ingram S.N., Baillie H.S., Gaitens P.V. (1992) Sperm structure and ultrastructure in the Hymenoptera (Insecta), Zool. Scr. 21, 381-410.

Rasnitsyn A.P. (1988) An outline of evolution of the hymenopterous insects (Order Vespida), Orient. Insects 22, 115-145.

Riemann J.G. (1973) Ultrastructure of the ejaculatory duct region producing the male housefly accessory material, J. Insect Physiol. 19, 213-223.

Ronquist F., Rasnitsyn A.P., Roy A., Eriksson K., Lindgren M. (1999) Phylogeny of the Hymenoptera: A cladistic reanalysis of Rasnitsyn's (1988) data, Zool. Scr. 28, 1350.

Schiff N., Flemming A.J., Quicke D.J.L. (2001) Spermatodesmata of the sawflies (Hymenoptera: Symphyta): evidences for multiple increases in sperm bundle size, J. Hymenopt. Res. 10, 119125.

Silveira F.A., Melo G.A.R., Almeida E.A.B. (2002) Abelhas Brasileiras: Sistemática e Identificação, IDM Composição e Arte, Belo Horizonte, p. 253.

Snodgrass R.E. (1978) Anatomy of the honey bees, Cornel University Press, London, p. 334.

Stefanini M., De Martino C., Zamboni L. (1967) Fixation of ejaculated spermatozoa for electron microscopy, Nature (London) 216, 173.

Sturm R. (2003) The spermatophore of the black field cricket Teleogryllus commodus
(Insecta: Orthoptera: Gryllidae): size, structure and formation, Entomol. Abh. 61, 227-232.

Tasei J.N., Moinard C., Moreu L., Himpens B., Guynnaud S. (1998) Relationship between aging, mating and sperm production in captive Bombus terrestris, J. Apicult. Res. 37, 107-113.

Velthuis H.H.W., Koedam D., Imperatriz-Fonseca V.L. (2005) The males of Melipona and other stingless bees, and their mothers, Apidologie 36, 169-185.

Viscuso R., Brundo M.V., Sottile L. (2005) Ultrastructural organization of the seminal vesicles of Baculum thaii (Phasmida, Phasmatidae) during sexual maturity, Ital. J. Zool. 72, 113-119.

Viscuso R., Narcisi L., Sottile L. (1999) Structure and function of the seminal vesicles of Orthoptera Tettigonioide,. Int. J. Insect Morphol. 28, 169178.

Wheeler D.E., Krutzsch P.H. (1992) Internal reproductive system in adult males of genus Camponotus (Hymenoptera: Formicidae: Formicinae), J. Morphol. 211, 307-317.

Zama U., Lino-Neto J., Dolder H. (2001) Ultrastructure of spermatozoa in Plebeia (Plebeia) droryana Friese (Hymenoptera: Apidae: Meliponina), J. Hym. Res. 10, 261-270.

Zama U., Lino-Neto J., Dolder H. (2004) Structure and ultrastructure of spermatozoa in Meliponini (stingless bees) (Hymenoptera: Apidae), Tissue Cell $36,29-41$.

Zama U., Lino-Neto J., Mello S.M., Campos L.A.O., Dolder H. (2005) Ultrastructural characterization of spermatozoa in euglossine bees (Hymenoptera. Apidae, Apinae), Insect. Soc. 52, 122-131. 